University of Nebraska - Lincoln

DigitalCommons@University of Nebraska - Lincoln

Publications, Agencies and Staff of the U.S.

Department of Commerce

U.S. Department of Commerce

2012

\title{
Spatial complexity in fragmenting Amazonian rainforests: Do feedbacks from edge effects push forests towards an ecological threshold?
}

\author{
Graeme S. Cumming \\ University of Cape Town, graeme.cumming@uct.ac.za \\ Jane Southworth \\ University of Florida \\ Xanic J. Rondon \\ University of Cape Town \\ Matthew Marsik \\ NOAA NW Fisheries Science Center
}

Follow this and additional works at: https://digitalcommons.unl.edu/usdeptcommercepub

Part of the Environmental Sciences Commons

Cumming, Graeme S.; Southworth, Jane; Rondon, Xanic J.; and Marsik, Matthew, "Spatial complexity in fragmenting Amazonian rainforests: Do feedbacks from edge effects push forests towards an ecological threshold?" (2012). Publications, Agencies and Staff of the U.S. Department of Commerce. 337. https://digitalcommons.unl.edu/usdeptcommercepub/337

This Article is brought to you for free and open access by the U.S. Department of Commerce at DigitalCommons@University of Nebraska - Lincoln. It has been accepted for inclusion in Publications, Agencies and Staff of the U.S. Department of Commerce by an authorized administrator of DigitalCommons@University of Nebraska - Lincoln. 


\title{
Spatial complexity in fragmenting Amazonian rainforests: Do feedbacks from edge effects push forests towards an ecological threshold?
}

\author{
Graeme S. Cumming a,*, Jane Southworth ${ }^{\mathrm{b}}$, Xanic J. Rondon ${ }^{\mathrm{a}, \mathrm{c}}$, Matthew Marsik ${ }^{\mathrm{d}}$ \\ a Percy FitzPatrick Institute, DST/NRF Centre of Excellence, University of Cape Town, Rondebosch, Cape Town 7701, South Africa \\ ${ }^{\mathrm{b}}$ Department of Geography, University of Florida, Gainesville, FL 32611-7315, United States \\ ${ }^{c}$ Center for Latin American Studies, University of Florida, Gainesville, FL 32611, United States \\ ${ }^{\mathrm{d}}$ The Natural Capital Project, c/o NOAA NW Fisheries Science Center, 2725 Montlake Blvd E, Seattle, WA 98112, United States
}

\section{A R T I C L E I N F O}

\section{Article history:}

Received 28 June 2011

Received in revised form 5 March 2012

Accepted 15 March 2012

Available online $\mathrm{xxx}$

\section{Keywords:}

Landscape ecology

Edge

Fire

Tipping point

Disturbance

Amazon

\begin{abstract}
A B S T R A C T
Deforestation and resulting landscape fragmentation are important concerns in many tropical areas. Deforestation is a complex process with many potential feedback loops, many of which are ignored in models that attempt to interpolate forest loss based on past deforestation rates. In addition, most ecological studies of the impacts of deforestation have focused on landscapes that are already fragmented. These studies ignore the fact that edge effects, such as anthropogenic fire, reach their maximum well before habitat connectivity is lost and may create positive feedbacks that result in further fragmentation. We developed a simple model to explore the potential influence of edge effects on fragmentation rates and used remotely sensed data from the MAP (Madre de Dios, Acre, and Pando) region of the Brazilian Amazon to parameterize the relationships of interest. Under reasonable real-world parameter combinations, edge effects can have a significant impact on deforestation rates, supporting the hypothesis that the true tipping point in a forest to pasture regime shift occurs earlier (i.e., $\sim 50 \%$ forest loss) than analysis of a loss in connectivity would suggest (i.e., $60 \%$ forest loss). Our results have important implications for understanding deforestation, edge-driven processes, regime shifts, and the management of complex pattern-process relationships.
\end{abstract}

(c) 2012 Elsevier B.V. All rights reserved.

\section{Introduction}

Tropical forests across the globe are under pressure from timber extraction and conversion for cattle ranching and crops (Asner et al., 2005; Morton et al., 2006; Nepstad et al., 2006a). Given the widespread nature of deforestation in the tropics (Myers, 1989; FAO, 1996; Achard et al., 2002), and the urgent need to regulate and manage both deforestation and its effects (Laurance et al., 2001; Soares-Filho et al., 2006; Nepstad et al., 2008), the development of a better understanding of the drivers of habitat loss and fragmentation is an important goal for research. Considerable progress has already been made in understanding the causes of deforestation. Complexity theory, with its emphasis on non-linearities, feedbacks, and adaptation, offers a natural context from which to further advance our understanding of the problem.

Forested landscapes in which people have substantial impacts can be viewed as social-ecological systems. When forests are fragmented by anthropogenic habitat destruction, they gradually

\footnotetext{
* Corresponding author. Tel.: +27 216503439.

E-mail addresses: graeme.cumming@uct.ac.za, gscumming@gmail.com (G.S. Cumming).
}

shift from being the dominant ('matrix') habitat to being patches in a matrix of pasture or crops. Over broad scales, this change can be considered a form of regime shift ('a rapid modification of ecosystem organization and dynamics, with prolonged consequences'; Carpenter, 2003; Folke et al., 2004) that has parallels to other regime shifts (e.g., that of a lake from an oligotrophic state to a eutrophic state under the influence of phosphorus loading; Carpenter et al., 1999; Scheffer et al., 2000), even though the rates of deforestation (and in a few cases, reforestation or afforestation) may be relatively slow.

The fragmented state of a forest-pasture system can exhibit high resilience as a consequence of self-reinforcing socialecological feedbacks, including such processes as crop planting, increased fire and human settlement in cleared areas, and the destruction of tree seedlings by livestock.

Theory predicts that regime shifts between different states will be driven by a set of non-linear relationships between important system variables. Non-linearities are particularly apparent during deforestation in the rates of change of edge effects, connectivity, and patch sizes (e.g., Gardner et al., 1987, 1992; Gustavson and Parker, 1992). The typically sigmoidal decline in forest connectivity during fragmentation, for example, has been shown to influence a range of important ecological processes (e.g., Tilman et al., 1994; Hobbs, 2001; Fahrig, 2003; Wu et al., 2003; Laurance et al., 2006). 


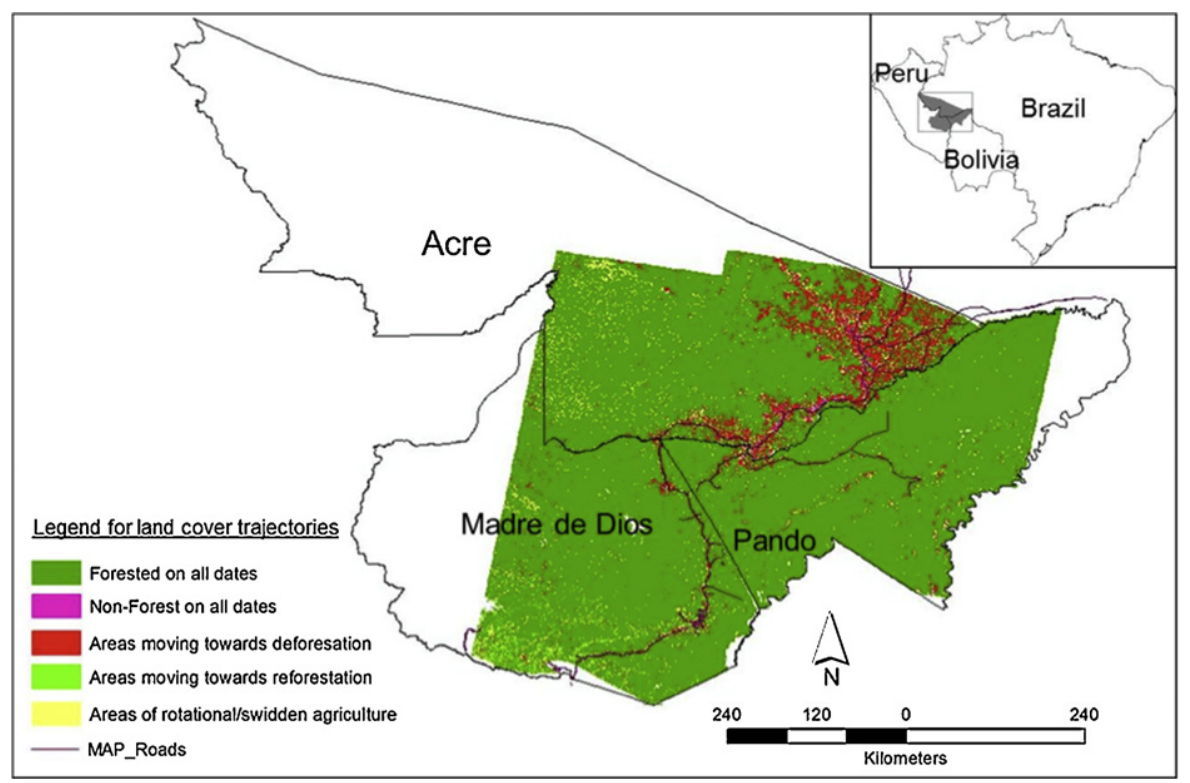

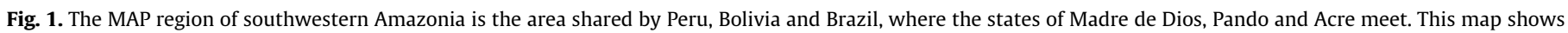
changes by pixel across the study region based on remotely sensed data from time steps 1986-1991-1995-2000-2005.

The focus in most previous forest fragmentation studies has been on forest patches (Murcia, 1995; Debinski and Holt, 2000), which are usually surrounded by a matrix of lower biomass and structural complexity, as in the case of pastures, croplands or fallows. By definition, forest patches occur in the later stages of fragmentation rather than in the earlier stages. Landscapes in a forested regime, in which forest is dominant (and the patches are clearings), appear less interesting in testing ecological theories because many ecological processes are assumed to remain unchanged until the fragmentation threshold of about $44 \%$ forest cover is reached (Gardner et al., 1987).

The classical focus on ecological connectivity as a driver of ecological processes (and hence, of ecosystem function) has tended to obscure the role of other non-linearities that occur during fragmentation, including that of edge effects. Empirical data suggest that edge effects are particularly important in our study system, the MAP region of southwestern Amazonia, which is in the early stages of forest fragmentation. MAP refers to the tri-national frontier area, where Peru, Bolivia and Brazil meet (the states of Madre de Dios, Acre, and Pando respectively; Fig. 1). This region is one of the most biologically diverse areas in the world (Myers et al., 2000; Ceballos and Ehrlich, 2006; Finer et al., 2008). Although the landscape of the MAP region still retains large tracts of connected and relatively undisturbed tropical forest, large infrastructural projects, as well as gas, oil, and logging, are rapidly penetrating the region (Laurance et al., 2001; IIRSA, 2005; Finer et al., 2008; Perz et al., 2008). The ecological consequences of deforestation and forest fragmentation in the Amazon are exacerbated by forest fires, which are largely associated with forest edges (Uhl and Buschbacher, 1985; Cochrane, 2001; Cochrane and Laurance, 2002).

Fire is an endemic disturbance in the Amazon (Saldarriaga and West, 1986; Meggers, 1994), but rarely occurs since forests have evergreen canopies, high humidity levels, stable temperatures, and little wind; and leaf litter decomposes rapidly (Sanford et al., 1985; Uhl et al., 1988; Nepstad et al., 1999b; Laurance et al., 2002a). By contrast, forest edges have elevated temperatures, reduced humidity, and increased wind speed relative to forest interiors (Kapos, 1989; Miller et al., 1991; Laurance, 1997; Didham and Lawton, 1999). Edge effects lead to increased tree mortality (Ferreira and Laurance, 1997; Laurance et al., 1998, 2000; D’Angelo et al., 2004), decreased living biomass (Laurance et al., 1997), and increased fuel loads (Nascimento and Laurance, 2002), increasing the vulnerability of fragmented forests to fires (Cochrane, 2001; Cochrane and Laurance, 2002). Forest fires usually move into forests from deforested land, and have been shown to frequently penetrate up to $2.5 \mathrm{~km}$ into the forest interior (Cochrane, 2001). Human activity is also higher at forest edges, causing accidental spread of fires into the forest (Uhl and Buschbacher, 1985; Cochrane and Schulze, 1999; Nepstad et al., 1999b; Cochrane et al., 1999; Cochrane, 2003) and increasing the susceptibility of previously burned forest to further burning (Nepstad et al., 1999b, 2001; Cochrane and Schulze, 1999; Cochrane et al., 1999). Fire occurrences are strongly human-influenced; areas with higher deforestation rates in the Amazon also tend to support greater numbers of fires (Eva and Fritz, 2003).

Given that edge effects occur together with declines in connectivity and patch size, and that all three of these variables (i.e., forest patch size, forest connectivity, and forest edge) change non-linearly with fragmentation, fragmenting landscapes have the potential to develop self-reinforcing feedback loops between fragmentation processes (fire, logging) and landscape pattern (connectivity, patch characteristics, and edge effects). These feedbacks may also create additional thresholds beyond which fragmentation occurs more rapidly and becomes far harder to limit or prevent. For instance, it is possible that feedbacks will exert a strong push on a forested social-ecological system well before more obvious declines in connectivity become evident, reducing the buffering capacity of the system and lowering its resilience.

In this paper, we explore the possible impact of a feedback from edge effects to forest loss on the rate of forest loss during fragmentation in the MAP region of the Amazon. We first propose a simple conceptual model and parameterize it using real-world data from the MAP region. We then use the model to ask (1) whether, and under what conditions, the presence of a realistic edge-dependent pattern-based feedback to forest loss might result in significant forest loss and (2) whether and how edge-fire feedbacks, which peak at a deforestation threshold some 6-10\% earlier in the deforestation process than the ecological connectivity threshold (i.e., 40-45\% remaining forest) might be relevant when the management objective is to maintain forest connectivity. 


\section{Methods}

\subsection{Study sites and empirical data}

Our study site was a relatively unfragmented area of the Amazon, the MAP region of southwestern Amazonia (Fig. 1), in which many of the processes that typically lead to fragmented forests are only beginning. This region encompasses roughly $300,000 \mathrm{~km}^{2}$ (Brown et al., 2002), and still contains large tracts of undisturbed tropical moist forest. The MAP region is one of the most biologically diverse areas in the world (Myers et al., 2000; Ceballos and Ehrlich, 2006; Finer et al., 2008), and it is also home to indigenous ethnic groups, forest extractivists, small farm colonists, large-scale ranchers, miners, logging firms, and growing urban populations (Brown et al., 2002). The population of the MAP region is $>926,000$ (INEI, 2007; IBGE, 2010; INE, 2011). It is part of the corridor along which the Inter-Oceanic Highway is being paved (IIRSA, 2005).

Rates of deforestation relative to road development vary across the MAP region. Acre has the highest deforestation rate, followed by Madre de Dios and then Pando (Southworth et al., 2011). MAP is a remote district of all three countries, with relatively low average incomes making road paving a major development priority. The Inter-oceanic highway will link southern Brazil, the Pacific coast of Peru, and central Bolivia (CEPEI, 2001). Road paving is expected to bring rapid changes in land use and livelihoods, with the prospect of substantial biodiversity loss, changes in land tenure (such as from extractive forest reserves to private agricultural holdings), and shifts to less sustainable livelihoods. This is a crucial historical moment at which to better understand the identity of the MAP region's forest-based economy in terms of how it responds to external shocks brought by migration, investment and new technologies in the wake of infrastructure upgrades (Brown et al., 2002; MAP, 2005).

The tri-national frontier has differing levels of infrastructure. Although the Interoceanic highway on the Brazilian side was paved by 2002 , it is currently under way on the Peruvian side, and paving on the Bolivian side is still in the planning stages. These differences allow for a comparison of land cover change under different conditions of road connectivity and transport costs. Rates of land cover change, specifically forest clearing, follow the trend of road paving in terms of rates and amount (Marsik et al., 2011).

We developed land cover maps for the study sites using remote sensing methods as described in detail in Marsik et al. (2011). Landsat 4 and 5 TM and Landsat 7 ETM+ images were acquired for 1986, 1991, 1996, 2000 and 2005 during the dry season (MayOctober), with each image date consisting of an eight image footprints mosaicked together. The images were corrected for atmospheric and seasonal differences and were georeferenced to less than 0.5 pixels or $15 \mathrm{~m}$. For the process of image classification, derived image products were generated for each mosaic, which included tasseled cap indices (Kauth and Lyndon, 1976), a midinfrared index (Boyd and Petitcolin, 2004) and a $3 \times 3$ pixel moving window variance calculation (as a measure of image texture) for bands 4,5 and 7 .

Due to the complex ecosystems and different eco-regions within the study region, image classification was undertaken using decision trees, which result in easily interpretable and explicit classification rules (Breiman, 1984). Data mining using Compumine software was used to create the decision rules for each mosaic. An 85/15 split-sample validation was used to create and to test the decision tree. This process was repeated for each mosaic date. The classification procedure used the near- and midinfrared bands along with secondary derived products previously described. Forest, pasture, and bare/built were the initial classification classes with pasture and bare/built aggregated

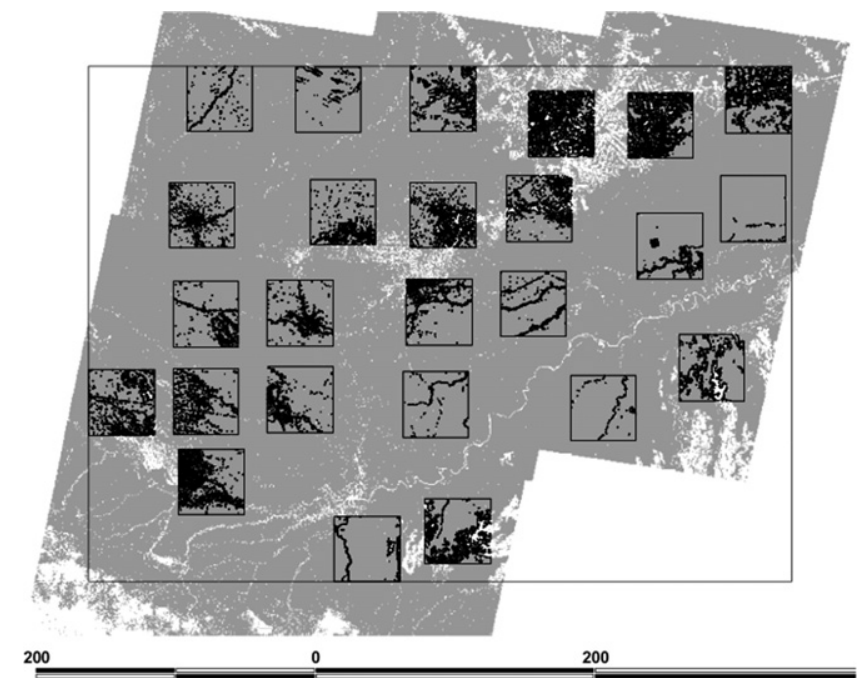

Fig. 2. Land cover in the MAP region in 2005 , showing $2550 \mathrm{~km} \times 50 \mathrm{~km}$ cells that were used to generate an empirically derived edge-area relationship. Forested areas are shaded grey and non-forest in white. The black boundaries show edges as quantified within each of the 25 units of analysis.

(post-classification) to create the non-forest class. This resulted in 5 image dates of forest/non-forest land cover classifications.

Overall, the decision rules distinguished the classes well (Marsik et al., 2011). An accuracy assessment of the resulting classified images was conducted by relating the imagery to field data collected during summer 2007. For the closest image date (2005), the forest/non-forest classified image, based on comparison with the 150 training samples collected was $87.85 \%$ overall accuracy, with an overall Kappa of 0.68 . Earlier dates could not be tested for accuracy due to a lack of data for field comparisons.

An exact imitation of regional deforestation (i.e., sampling a single area over a full set of steps from forested to cleared) is impossible because of the high data requirements, the slow rate of change in the real world, and the fact that much of the region is still forested. We therefore sampled subsets of the larger image that were at different stages of deforestation to capture the effects of what are essentially the same process(es) at different stages along a deforestation trajectory (i.e., we used a space for time substitution). Since we wanted to include the element of change through time within the same location, and because of the possibility that the basic spatial pattern of the deforestation process had changed in recent years, we included land cover data for each sampled area from two different time steps (1991 and 2005). We used these two time-steps from our available data set (see Southworth et al., 2011) because they represented our longest consistently measured (same satellite platform) time step, and hence provided the most reliable data set for determining longterm average relationships between different variables. The forest trajectories map (Fig. 1), as derived from the 1985 through 2005 forest non-forest land cover maps, illustrates this nicely at a pixel level.

We extracted $2550 \mathrm{~km} \times 50 \mathrm{~km}$ raster areas of interest (Fig. 2) from the 1991 and the 2005 images, respectively. This yielded a sample of 50 different area-edge pairs that were autocorrelated in time (i.e., same location sampled at two different points along a deforestation trajectory) and in space (i.e., through proximity to one another). Each raster was converted to vector format in ERDAS Imagine 9.3. We used ArcMap 9.2 and FRAGSTATS to calculate total forested area, forest edge, number of patches, and connectivity for each area of interest. The "artificial" edges on the perimeter of each $50 \mathrm{~km} \times 50 \mathrm{~km}$ grid were included as edge in the analysis. Bivariate plots of different variables were used to determine 
(a)

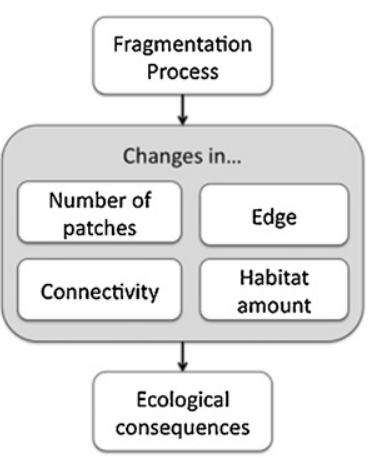

(b)

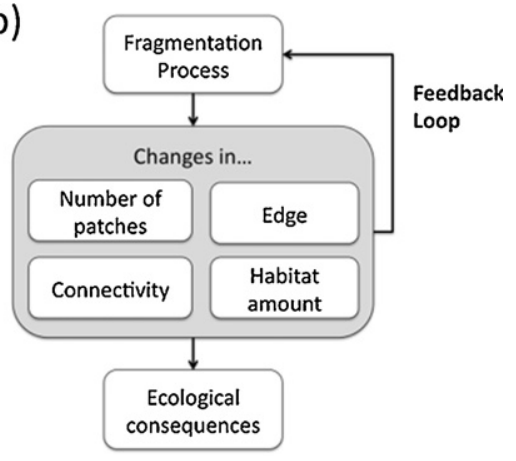

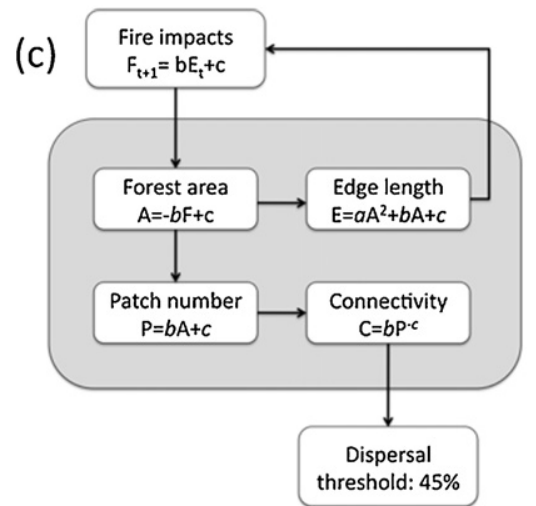

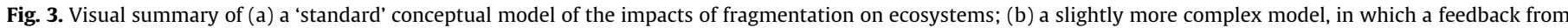

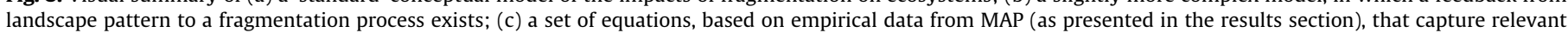
pattern-process relationships. The constants $a, b$ and $c$ are used here to express the form of each equation and have different values between equations.

suitable forms of equations and parameters for the development of a simple simulation model, as discussed in the next section.

\subsection{Model development and rationale}

Most fragmentation-related analyses have relied, whether implicitly or explicitly, on a relatively simple conceptual model, which assumes that fragmentation processes reduce forest cover, altering ecological patterns and processes and impacting ecosystems. The possibility for feedbacks from ecosystems, for instance via changes in populations of seed dispersers as a result of disruptions in connectivity, has also been considered. Few analyses, however, have considered the possibility that patterndriven feedbacks at a broad scale may amplify (or alternatively, regulate) fragmentation processes (Fig. 3).

The aim of our modelling analysis was to determine whether, or under what conditions, edge-related feedbacks may significantly influence deforestation rates (and hence, habitat connectivity as seen from an organismal perspective). Edge is a potential 'multiplier' of forest loss in the sense that in the early stages of deforestation, the loss of more forest usually results in more edges, which in turn may lead to the loss of more forest. Edge-related processes reach a maximum at around $50 \%$ of forest loss, while connectivity-related thresholds are only attained later along a deforestation trajectory (i.e., at $<40-$ $45 \%$ remaining forest). If high amounts of edge create selfamplifying deforestation feedbacks, then at the maximum amount of edge in a landscape (50\% remaining forest) the system may already have such significant momentum towards further forest loss that the maintenance of connectivity is virtually impossible. If this is the case, then management that aims to keep forest cover above $45 \%$ to maintain dispersal-related processes may in fact need to prevent edge from being maximized (i.e., at $50 \%$ ) by observing a still lower deforestation threshold (say, 60\% forest cover).

It is almost inevitable that under comparable parameter choices, an equation which incorporates a multiplicative term will result in a faster rate of change than an additive or subtractive linear equation. The focal question to be resolved through the development of the model was not simply that of whether or not a model that included an edge-related feedback could produce faster forest loss than a linear model (we know that it could, even before we start). Rather, the question of interest was whether the realworld magnitudes of edge effects (i.e., at scales of tens to hundreds of metres) are large enough to exert a detectable influence on existing rates of deforestation over larger areas. It was therefore important that we used realistic numbers throughout the analysis and based the analysis solidly on real-world data, as described above.

Analysis of the problem is complicated by the fact that we have no true control for deforestation at this scale, and hence we do not know whether observations made on existing landscapes (such as empirical relationships that relate deforestation rates and edge creation, for example) include or exclude the kinds of dynamic that would be expected if an edge-related feedback is in place. In our view the weight of published evidence supports the hypothesis that feedbacks from edge creation to increased amounts of fire in the Amazon influence deforestation rates. We therefore adopted the stance that observed pattern-process relationships were consistent with a feedback mechanism, and focused on developing a null model that excluded feedbacks, rather than taking the alternative route of first fitting a linear model to our existing data and then adding feedbacks. 


\section{Results}

The MAP data suggested that in this region there is a set of strong and statistically significant relationships between forest area and each of edge and patch number, and between patch number and connectivity. In all cases, the significance of the relationship was below 0.05 and $r^{2}$ values for the least-squares fit of a regression model were over 0.65 (Fig. 4 and Table 1 ).

We used these results, together with the conceptual model presented in Fig. 3, to parameterize our deforestation model (hereafter termed 'FRED', for 'Fire \& Edge'). With the constant $a$ in the fire equation (Table 1 ) set to zero and $c$ negative, the edgedriven feedback is excluded and FRED produces a linear decline in forest cover. This linear model was used as a null model against which we assessed the relative importance of edge effects under different assumptions about their magnitude.

FRED suggests that relative to a linear deforestation rate (with magnitudes between 10 and $100 \mathrm{~km}^{2} / \mathrm{yr}$ per $50 \mathrm{~km} \times 50 \mathrm{~km}$ unit of analysis, or ranging from $0.025 \%$ to $0.25 \%$ of forested area within a given $50 \mathrm{~km} \times 50 \mathrm{~km}$ unit of analysis), an edge-driven amplification of the deforestation process with a magnitude in the range of $10-500 \mathrm{~m}$ can result in significant deforestation. In the absence of any additional deforestation, a consistent loss of $100 \mathrm{~m}$ of forest edge per year leads to the loss of nearly all forest in the entire $2500 \mathrm{~km}^{2}$ unit of analysis within 54 years (Fig. 5).

When linear forest loss is combined with even a relatively small edge effect, near-complete forest loss is achieved far more rapidly (Fig. 6). With a consistent edge effect of $50 \mathrm{~m}$ or more in tandem with an additional annual loss of $0.04 \%$ of forest cover, complete forest loss in a single $50 \mathrm{~km} \times 50 \mathrm{~km}$ unit occurs in just 8 years. In this case, the non-linearity of edge effects results in a much sharper decline in forest cover than a linear deforestation process.

\section{Discussion}

Our analysis demonstrates at least three important points. The first is that clear-cut and readily modelled relationships exist between forest area, edge, patch numbers, and connectivity within the MAP region; it is therefore possible to model the interactions between different remotely sensed measures of forest loss in a rigorous and consistent manner. Second, if we combine these different elements in a simple but empirically sound model, we find that if small edge effects are present, they can lead (under realistic assumptions of their magnitudes) to far faster declines in forest cover than those that occur than under a linear deforestation model. Third, and more generally, when thinking about land cover change and percolation thresholds in landscapes, this exercise illustrates the importance of moving beyond simplistic assumptions of linear change to the consideration of synergies in fragmentation mechanisms, particularly where well-documented non-linearities between key variables exist.

The heavily destructive edge-related feedbacks that are envisaged in this model are of course unlikely to act along an entire edge, and their actual impact in real-world situations is unlikely to be quite as high as our model implies. Real-world
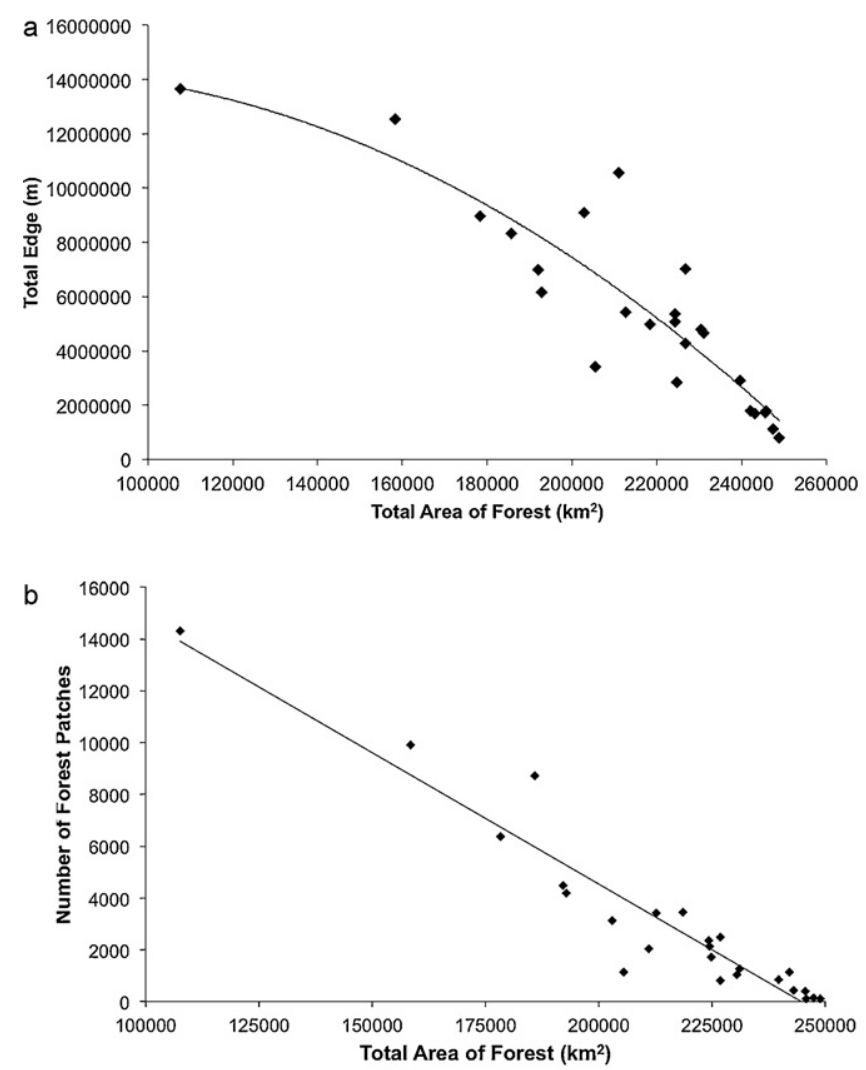

C

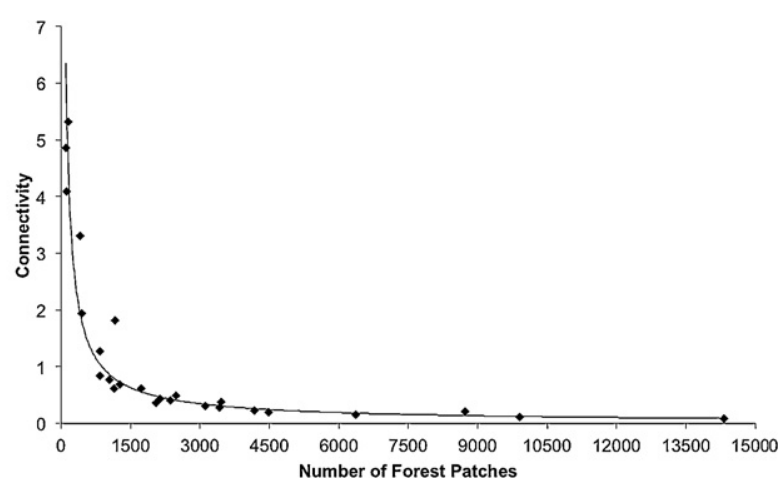

Fig. 4. Empirical relationships in the MAP region between forest area ( $x$ axis) and (a) edge and (b) number of patches; (c) between number of patches and overall landscape connectivity. All relationships are significant, as summarized in Table 1. The most heavily deforested point on the plot in (a) includes the towns and surroundings of Cobija (state capital of Pando, Bolivia), Brasiléia (sixth largest town in Acre, Brazil), and Epitaciolândia (the southernmost town in Acre, Brazil).

forests also regrow over time. However, if fire affects just $10 \%$ of edges and acts only along a narrow strip of $50 \mathrm{~m}$ from the forest edge, our results suggest that edge-related fire together with an annual removal of just $10 \mathrm{~km}^{2}$ of forest could completely deforest a $2500 \mathrm{~km}^{2}$ piece of the Amazonian landscape within 40 years. The

Table 1

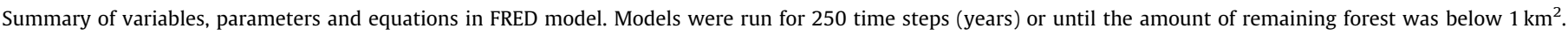

\begin{tabular}{|c|c|c|}
\hline Variable & Equation & Comments and supporting statistics \\
\hline$F$ : Fire area & $\begin{array}{l}F=a E+c \text { ( } a \text { is a constant that describes the extent of } \\
\text { the edge effect; it was varied between simulations). }\end{array}$ & $\begin{array}{l}\text { Based on Eva and Fritz (2003), the use of a linear relationship } \\
\text { is appropriate. }\end{array}$ \\
\hline$A$ : Forested area $\left(\mathrm{km}^{2}\right)$ & $\begin{array}{l}A_{t+1}=A_{t}-F_{t} \\
A \text { starts at } 2500 \mathrm{~km}^{2} \text { in each simulation. }\end{array}$ & Model assumes a sequential decline with no regeneration. \\
\hline$P:$ Number of patches & $-10.15 A+24828$ & $r^{2}=0.91, p<0.005, n=50$ \\
\hline$E$ : Length of edge $(\mathrm{km})$ & $-0.0073 A^{2}+18.7 A$ & $r^{2}=0.68, p<0.005, n=50$ \\
\hline C: Connectivity & $348 P^{-0.864}$ & $r^{2}=0.94, p<0.005, n=50$ \\
\hline
\end{tabular}




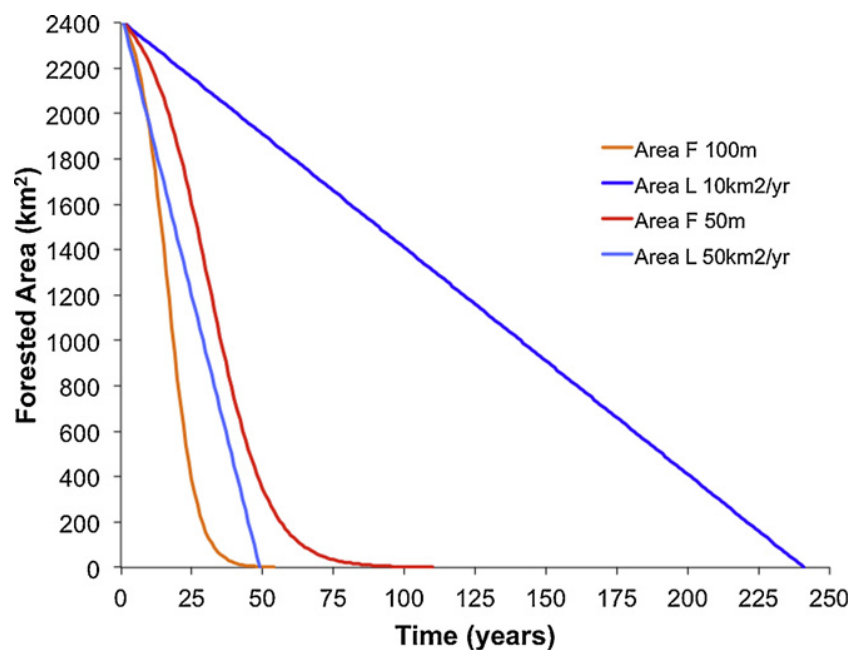

Fig. 5. Decline in forest area under edge feedback models ('F') at $50 \mathrm{~m}$ and $100 \mathrm{~m}$ (first and third lines from left) and under linear deforestation models ('L') of $10 \mathrm{~km}^{2} /$ $\mathrm{yr} / 2500 \mathrm{~km}^{2}$ and $50 \mathrm{~km}^{2} / \mathrm{yr} / 2500 \mathrm{~km}^{2}$ (second and fourth lines from left).

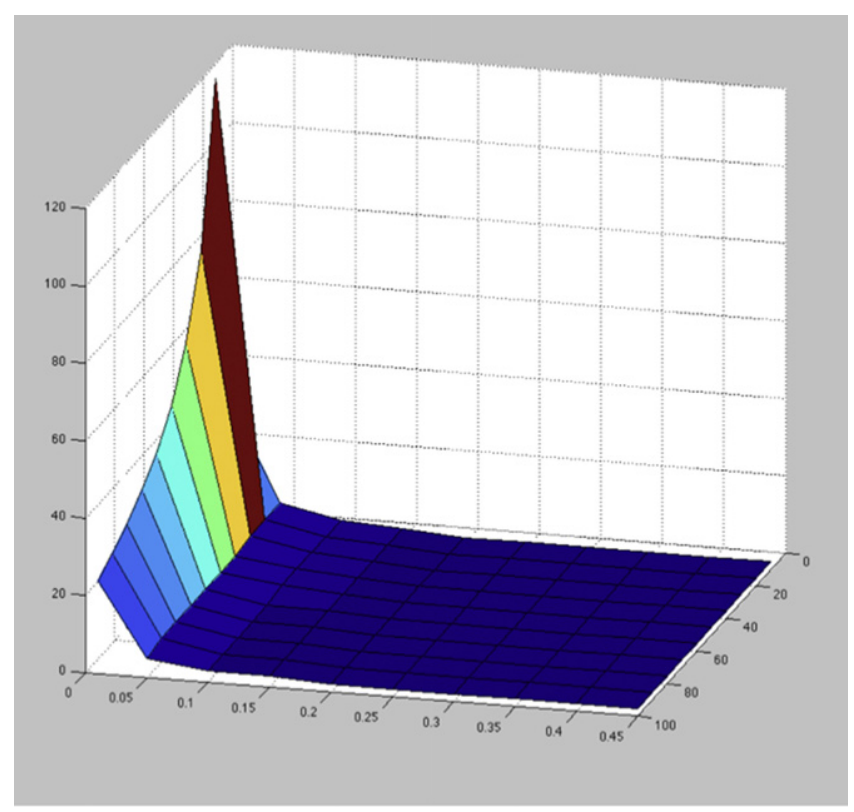

Fig. 6. Relationships between time to forest loss ( $z$ axis, in years), edge effect size ( $x$ axis, from $10 \mathrm{~m}$ to $450 \mathrm{~m}$ in units of $\mathrm{km}$ ), and annual forest loss from non-edgerelated causes (on $y$ axis, in units of $\mathrm{km}^{2}$ ).

importance of edge-related forest destruction is thus potentially very high.

A regime shift from forest to complete forest loss is in reality a relatively severe scenario; but as discussed in the introduction, many of the more important ecological impacts of deforestation will occur considerably earlier in a deforestation trajectory. Our model suggests that edge-related feedbacks can significantly amplify the effects of deforestation that results from other causes, reducing the time until a loss of connectivity occurs. In a broader theoretical context, the principle is clear: patternrelated feedbacks, such as those between edges and fire, have the potential to act as drivers of change that push forested systems towards social-ecological tipping points (i.e., across a connectivity threshold into a pasture-dominated state) and may further serve to buffer and sustain a fragmented landscape.
Land-climate models for the Amazon predict that anthropogenic global warming in the 21 st century alone could shift wet humid forests into a semi-arid savanna vegetation (e.g., Cox et al., 2000, 2004; Botta and Foley, 2002; Oyama and Nobre, 2003). These models may be overly conservative because they do not include the positive feedbacks between other factors such as land-use change, road construction, edge effects, forest fires and drought that have been described for the region (Cochrane et al., 1999; Nepstad et al., 1999a,b, 2001; Laurance et al., 2002b; Perz et al., 2008). Therefore, the periodically voiced argument that forest loss up to $50 \%$ in the landscape matrix will retain landscape connectivity, and should serve as an adequate conservation target or threshold of potential concern (e.g., Soares-Filho et al., 2006), seems far too optimistic. The potentially strong push exerted by edge effects on the system means that maintaining forest cover well over 50\% may be necessary to avoid crossing a tipping point.

Better management practices in the landscape matrix will be necessary to achieve conservation goals (Franklin and Lindenmayer, 2009). In the Brazilian Amazon alone, deforestation and logging are creating up to $38,000 \mathrm{~km}$ of new forest edge annually (Broadbent et al., 2008). Furthermore, severe droughts are already taking place in the Amazon. The 2005 drought in the Amazon created conditions in the MAP region for fires to escape, burning over 300,000 ha of primary forest with economic losses of US $\$ 50$ million (Brown et al., 2006; Marengo et al., 2008). Although protected areas are effective for reducing deforestation and fire in the Amazon (Nepstad et al., 2006b; Adeney et al., 2009), they cover a small portion of the landscape and many are impoverished by logging, making them more vulnerable to fires (Holdsworth and Uhl, 1997; Siegert et al., 2001; Cochrane and Laurance, 2002).

Our analysis suggests that a reduction in the rates of edge creation should be one of the priorities in both conservation and fire management strategies for the MAP region. Although the dominant land cover in the region is still forest, with over $89 \%$ of the landscape under stable forest cover from 1985 to 2005 (Southworth et al., 2011; Fig. 1), the three countries that make up the MAP region have different deforestation rates. Acre, Brazil, is the most heavily deforested area, followed by Madre de Dios in Peru and Pando in Bolivia (Southworth et al., 2011). The influence of road developments on forest clearing is evident in Acre up to $45 \mathrm{~km}$ from the road, and in Madre de Dios up to $18 \mathrm{~km}$ (Southworth et al., 2011). Deforestation and edge effects in this region will further increase with the implementation of large infrastructural projects (e.g., Laurance et al., 2002a,b; Nepstad et al., 2001; Fearnside, 2007). Planning policies that foster clustered development should be encouraged, instead of linear or ramifying development, because they produce the least amount of edge. As part of a fire management plan, land-holders will need to reduce the use of fire as a management tool for burning felled forest in preparation for crops or pastures, and invest more in the prevention of accidental fires (Nepstad et al., 2001). Improving access to weather information, fire safety training for land owners, and strictly enforced burn-bans during dry periods may also decrease the number of forest fires occurring in the Amazon (Moran et al., 2006). These policies and management plans will have to be designed accordingly for each country, taking into account their socio-economic context.

Lastly, and more generally, our analysis demonstrates that when different mechanisms can potentially interact in non-linear ways to cause a complex system to cross a threshold, the relative timing of these mechanisms is important. Edge in this example peaks earlier and faster than the loss of connectivity, creating a 'slippery slope' that may make it far harder than expected to keep the system away from a connectivity threshold. When developing early warning systems to detect looming ecological thresholds, 
analyses that take full account of feedbacks and non-linearities are essential if unpleasant surprises are to be avoided.

\section{Acknowledgements}

We are grateful to our many collaborators and colleagues who have contributed to the MAP program, and particularly to co-PIs Steve Perz and Grenville Barnes. This research was funded by NSF Human and Social Dynamics Grant 0527511 awarded to the University of Florida.

\section{References}

Achard, F., Eva, H.D., Stibig, H.-J., Mayaux, P., Gallego, J., Richards, T., Malingreau, J.P., 2002. Determination of deforestation rates of the world's humid tropical forests. Science 297, 999-1002.

Adeney, J.M., Christensen Jr., N.L., Pimm, S.L., 2009. Reserves protect against deforestation fires in the Amazon. PLoS One 4 (4), e5014.

Asner, G.P., Knapp, D.E., Broadbent, E.N., Oliveira, P.J.C., Keller, M., Silva, J.N., 2005 Selective logging in the Brazilian Amazon. Science 310, 480-482.

Broadbent, E.N., Anser, G.P., Keller, M., Knapp, D.E., Oliveira, P.J.C., Silva, J.N., 2008 Forest fragmentation and edge effects from deforestation and selective logging in the Brazilian Amazon. Biological Conservation 141, 1745-1757.

Brown, I.F., Schroeder, W., Setzer, A., Maldonado, M., de, L.R., Pantoja, N., Duarte, A. Marengo, J.A., 2006. Monitoring fires in Southwestern Amazonia rain forests. Eos 87, 253-264, doi:10.1029/2006EO260001.

Botta, A., Foley, J.A., 2002. Effects of climate variability and disturbances on the Amazonian terrestrial ecosystems dynamics. Global Biogeochemical Cycles 16, 1070.

Boyd, D., Petitcolin, F., 2004. Remote sensing of the terrestrial environment using middle infrared radiation (3.0-5 $\mu \mathrm{m})$. International Journal of Remote Sensing $25,3343-3368$.

Breiman, L., 1984. Classification and Regression Trees. Chapman \& Hall, Belmont CA, p. 368.

Brown, I.F., Brilhante, S.H.C., Mendoza, E., Ribeiro de Oliveira, I., 2002. Estrada de Rio Branco, Acre, Brasil aos portos do Pacífico: como maximizar os benefícios minimizar os prejuízos para o desenvolvimento sustentavel da Amazônia sulocidental. CEPEI, La integración regional entre Bolivia, Brasil y Peru, Lima, Peru, pp. 281-296.

Carpenter, S.R., 2003. Regime Shifts in Lake Ecosystems: Pattern and Variation. Excellence in Ecology Series 15, Ecol. Inst., Oldendorf/Luhe, Germany.

Carpenter, S.R., Ludwig, D., Brock, W.A., 1999. Management of eutrophication for lakes subject to potentially irreversible change. Ecological Applications 9, 751 771.

Ceballos, G., Ehrlich, P.R., 2006. Global mammal distributions, biodiversity hotspots, and conservation. Proceedings of the National Academy of Sciences of the United States of America 103, 19374-19379.

CEPEI, 2001. La Integración Regional Entre Bolivia, Brasil y Peru. CEPEI, Lima.

Cochrane, M.A., 2003. Fire science for rainforests. Nature 421, 913-919.

Cochrane, M.A., Alencar, A., Schulze, M.D., Souza, C.M., Nepstad, D.C., Lefebvre, P. Davidson, E., 1999. Positive feedbacks in the fire dynamics of closed canopy tropical forests. Science 284, 1832-1835.

Cochrane, M.A., Schulze, M.D., 1999. Fire as a recurrent event in tropical forests of the eastern Amazon: effects on forest structure, biomass, and species composition. Biotropica 31, 2-16.

Cochrane, M.A., 2001. Synergistic interaction between habitat fragmentation and fire in evergreen tropical forests. Conservation Biology 15, 1515-1521.

Cochrane, M.A., Laurance, W.F., 2002. Fire as a large-scale edge effect in Amazonian forests. Journal of Tropical Ecology 18, 311-325.

Cox, P.M., Betts, R.A., Collins, M., Harris, P.P., Huntingford, C., Jones, C.D., 2004 Amazonian forest dieback under climate-carbon cycle projections for the $21 \mathrm{st}$ century. Theoretical and Applied Climatology 78, 137-156.

Cox, P.M., Betts, R.A., Jones, C.D., Spall, S.A., Totterdell, I.J., 2000. Acceleration of global warming due to carbon-cycle feedbacks in a coupled climate model. Nature 408, 184

D’Angelo, S., Andrade, A., Laurance, S.G., Laurance, W.F., Mesquita, R., 2004. Inferred causes of tree mortality in fragmented and intact Amazonian forests. Journal of Tropical Ecology 20, 243-246.

Debinski, D.M., Holt, R.D., 2000. Review: a survey and overview of habitat fragmentation experiments. Conservation Biology 14, 342-355.

Didham, R.K., Lawton, J.H., 1999. Edge structure determines the magnitude of changes in microclimate and vegetation structure in tropical forest fragments. Biotropica 31, 17-30.

Eva, H., Fritz, S., 2003. Examining the potential of using remotely sense fired data to predict areas of rapid forest change in South America. Applied Geography 23, 189-204.

Fahrig, L., 2003. Effects of habitat fragmentation on biodiversity. Evolution and Systematics 34, 487-515.

FAO, 1996. Forest Resources Assessment 1990. Survey of Tropical Forest Cover and Study of Change Processes. FAO Forestry Paper 130, FAO, Rome.
Fearnside, P.M., 2007. Brazil's Cuiaba-Santarem (BR-163) highway: the environmental cost of paving a soybean corridor through the Amazon. Environmental Management 39, 601-614.

Ferreira, L.V., Laurance, W.F., 1997. Effects of forest fragmentation on mortality and damage of selected trees in central Amazonia. Conservation Biology 11, 797801.

Finer, M., Jenkins, C.N., Pimm, S.L., Keane, B., Ross, C., 2008. Oil and gas projects in the Western Amazon: threats to wilderness, biodiversity, and indigenous peoples. PLoS One 3 (8), e2932.

Folke, C., Carpenter, S., Walker, B., Scheffer, M., Elmqvist, T., Gunderson, L., Holling, C.S., 2004. Regime shifts, resilience, and biodiversity in ecosystem management. Annual Review of Ecology Evolution and Systematics 35, 557-581.

Franklin, J.F., Lindenmayer, D.B., 2009. Importance of matrix habitats in maintaining biological diversity. Proceedings of the National Academy of Sciences 106, 349350.

Gardner, R.H., Milne, B.T., Turner, M.G., O'Neill, R.V., 1987. Neutral models for the analysis of broad-scale landscape pattern. Landscape Ecology 1, 19-28.

Gardner, R.H., Turner, M.G., O’Neill, R.V., Lavorel, S., 1992. Simulation of the scaledependent effects on landscape boundaries on species persistence and dispersal. In: Holland, M.M., Risser, P.G., Naiman, R.J. (Eds.), The role of Landscape Boundaries in the Management and Restoration of Changing Environments. Chapman and Hall, New York, NY, pp. 76-898.

Gustavson, E.J., Parker, G.R., 1992. Relationships between landcover proportion and indices of landscape spatial pattern. Landscape Ecology 7, 101-110.

Hobbs, R.J., 2001. Synergisms among habitat fragmentation, livestock grazing, and biotic invasions in southwestern Australia. Conservation Biology 15, 15221528.

Holdsworth, A.R., Uhl, C., 1997. Fire in the eastern Amazonian logged rain forest and the potential for fire reduction. Ecological Applications 7, 713-725.

IBGE, 2010. Instituto Brasileiro de Geografia e Estatística. Censo 2010: população do Brasil é de 190.732 .694 pessoas. , http://www.ibge.gov.br.

IIRSA, 2005. Integración Suramericana. (See http://www.caf.com/view/index.asp).

INE, 2011. Instituto Nacional de Estadistica. Proyecciones de Población Nacional y Departamental. , In: http://www.ine.gob.bo.

INEI, 2007. Instituto Nacional de Estadistica e Informática. Perfil sociodemográfico del departamento de Madre de Dios. , In: http://www.inei.gob.pe.

Kapos, V., 1989. Effects of isolation on the water status of forest patches in the Brazilian Amazon. Journal of Tropical Ecology 5, 173-185.

Kauth, R.J., Lyndon, B.J.S.C., 1976. System for Analysis of Landsat Agricultural Data: Automatic Computer-Assisted Proportion Estimation of Local Areas. Environmental Research Institute of Michigan, Ann Arbor, MI, p. 11.

Laurance, W.F., 1997. Hyper-disturbed parks: edge effects and the ecology of isolated rainforest reserves in tropical Australia. In: Laurance, W.F., Bierregaard, R.O. (Eds.), Tropical Forest Remnants: Ecology, Management, and Conservation of Fragmented Communities. University of Chicago Press, Chicago, IL, pp. 71-83.

Laurance, W.F., Laurance, S.G., Ferreira, L.V., Rankin-de Merona, J., Gascon, C., Lovejoy, T.E., 1997. Biomass collapse in Amazonian forest fragments. Science 278, 1117-1118.

Laurance, W.F., Ferreira, L.V., Rankin-De Merona, J.M., Laurance, S.G., 1998. Rainforest fragmentation and the dynamics of Amazonian tree communities. Ecology 79, 2032-2040.

Laurance, W.F., Delamonica, P., Laurance, S.G., Vasconcelos, H.L., Lovejoy, T.E., 2000. Rainforest fragmentation kills big trees. Nature 404, 836.

Laurance, W.F., Cochrane, M.A., Bergen, S., Fearnside, P.M., Dela-monica, P., Barber C., D'Angelo, S., Fernandes, T., 2001. The future of the Brazilian Amazon. Science 291, 438-439.

Laurance, W.F., Albernaz, A.K.M., Schroth, G., Fearnside, P.M., Ventincinque, E., Da Costa, C., 2002a. Predictors of deforestation in the Brazilian Amazon. Journal of Biogeography 29, 737-748.

Laurance, W.F., Lovejoy, T.E., Vasconcelos, H.L., Bruna, E.M., Didham, R.K., Stouffer, P.C., Gascon, C., Bierregaard, R.O., Laurance, S.G., Sampaio, E., 2002b. Ecosystem decay of Amazonian forest fragments: a 22-year investigation. Conservation Biology 16, 605-618.

Laurance, W.F., Nascimento, H.E.M., Laurance, S.G., Andrade, A.C., Fearnside, P.M. Ribeiro, J.E.L., Capretz, R.L., 2006. Rainforest fragmentation and the proliferation of successional trees. Ecology 87, 469-482.

MarengoF J.A., Nobre, C.A., Tomasella, J., Cardoso, M.F., Oyama, M.D., 2008. Hydroclimatic and ecological behaviour of the drought of Amazonia in 2005. Philosophical Transactions of the Royal Society B 363, 1773-1778.

MAP, 2005. URL available at http://www.map-amazonia.net.

Marsik, M., Stevens, F., Southworth, J., 2011. Amazon deforestation: rates and patterns of land cover change and fragmentation in Pando, northern Bolivia, 1986 to 2005. Progress in Physical Geography 35 (3), 353-374.

Meggers, B.J., 1994. Archeological evidence for the impact of mega-Ninio events on Amazonian during the past two millennia. Climatic Change 28, 321-338.

Miller, D.R., Lin, J.D., Lu, Z., 1991. Some effects of surrounding forest canopy architecture on the wind field in small clearings. Forest Ecology and Management 45, 79-91.

Moran, E., Adams, R., Bakoyema, B.T.S., Boucek, B., 2006. Human strategies for coping with El Niño related drought in Amazonia. Climatic Change 77, 343-361.

Morton, D.C., DeFries, R.S., Shimabukuro, Y.E., Anderson, L.O., Arai, E., EspiritoSanto, F.D.B., Freitas, R., Morisette, J., 2006. Cropland expansion changes deforestation dynamics in the southern Brazilian Amazon. Proceedings of the National Academy of Sciences of the United States of America 103, 14637-14641. 
Murcia, C., 1995. Edge effects in fragmented forests: implications for conservation. Trends in Ecology and Evolution 10, 58-62.

Myers, N., 1989. Deforestation Rates in Tropical Forests and their Climate Implications. Friends of the Earth, London.

Myers, N., Mittermeier, R.A., Mittermeier, C.G., da Fonseca, G.A.B., Kent, J., 2000. Biodiversity hotpots for conservation priorities. Nature 403, 853-858.

Nascimento, H.E.M., Laurance, W.F., 2002. Total aboveground biomass in central Amazonian rainforests: a landscape-scale study. For. Ecol. Manage. 168, 311-321.

Nepstad, D.C., Moreira, A.G., Alencar, A.A., 1999a. Flames in the Rain Forest: Origins, Impacts, and Alternatives to Amazonian Fires. Pilot Program to Preserve the Brazilian Rain Forest, Brasilia, Brazil.

Nepstad, D.C., Verissimo, A., Alencar, A., Nobre, C., Lima, E., Lefebre, P., Schlesinger, P., Potter, C., Moutinho, P., Mendoza, E., Cochrane, M., Brooks, V., 1999b. Largescale impoverishment of Amazonian forests by logging and fire. Nature 398, 505-508.

Nepstad, D.C., Carvalho, G., Barros, A.C., Alencar, A., Capobianco, J.P., Bishop, J. Moutinho, P.R., Lefebvre, P.A., Silva, U.L., Prins, E., 2001. Road paving, fire regime feedbacks, and the future of Amazon forests. Forest Ecology and Management 154, 395-407.

Nepstad, D.C., Stickler, C.M., Almeida, O.T., 2006a. Globalization of the Amazon soy and beef industries: opportunities for conservation. Conservation Biology 20, 1595-1603.

Nepstad, D.C., Schwartzman, S., Bamberger, B., Santilli, M., Ray, D., et al., 2006b. Inhibition of Amazon deforestation and fire by parks and indigenous lands. Conservation Biology 20, 65-73.

Nepstad, D., Stickler, C., Soares-Filho, B., Brando, P., Merry, F., 2008. Ecological, economic, and climatic tipping points of an Amazon forest dieback. Philosophical Transactions of the Royal Society B.

Oyama, M.D., Nobre, C.A., 2003. A new climate-vegetation equilibrium state for Tropical South America. Geophysical Research Letters 30, 2199.
Perz, S., Brilhante, S., Brown, F., Caldas, M., Ikeda, S., Mendoza, E., Overdevest, C., Reis, V., Reyes, J.F., Rojas, D., Schmink, M., Souza, C., Walker, R., 2008. Road building, land use and climate change: prospects for environmental governance in the Amazon. Philos Trans R Soc B 363, 1889-1895.

Saldarriaga, J., West, D.C., 1986. Holocene fires in the northern Amazon basin. Quaternary Research 26, 358-366.

Sanford, R.L., Saldarriaga, J., Clark, K., Uhl, C., Herrera, R., 1985. Amazon rainforest fires. Science 227, 53-55.

Scheffer, M., Brock, W., Westley, F., 2000. Mechanisms preventing optimum use of ecosystem services: an interdisciplinary theoretical analysis. Ecosystems 3, $451-471$.

Siegert, F., Ruecker, G., Hinrichs, A., Hoffman, A.A., 2001. Increased damage from fires in logged forests during droughts caused by El Niño. Nature 414, 437-440.

Soares-Filho, B., Nepstad, D., Curran, L., Cerqueira, G., Garcia, R., Ramos, C., Voll, E., McDonald, A., Lefebvre, P., Schlesinger, P., 2006. Modeling Amazon conservation. Nature 440, 520-523.

Southworth, J., Marsik, M., Qiu, Y., Perz, S., Cumming, G., Stevens, F., Rocha, K., Duchelle, A., Barnes, G., 2011. Roads as drivers of change: trajectories across the Tri-National Frontier in MAP, the Southwestern Amazon. Remote Sensing 3, 1047-1066.

Tilman, D., May, R.M., Lehman, C.L., Nowak, M.A., 1994. Habitat destruction and the extinction debt. Nature 370, 66.

Uhl, C., Buschbacher, R., 1985. A disturbing synergism between cattle-ranch burning practices and selective tree harvesting in the eastern Amazon. Biotropica 17, 265-268.

Uhl, C., Kauffman, J.B., Cummings, D.L., 1988. Fire in the Venezuelan Amazon: environmental conditions necessary for forest fires in the evergreen rainforest of Venezuela. Oikos 53, 176-184.

Wu, J., Huang, J., Han, X., Xie, Z., Gao, X., 2003. Three-gorges dam-experiment in habitat fragmentation? Science 300, 1239-1240. 